\title{
North Fennoscandian mountain forests : History, composition, disturbance dynamics and the unpredictable future
}

\section{Kuuluvainen, Timo}

2017-02-01

Kuuluvainen, T , Hofgaard , A , Aakala , T \& Jonsson , B G 2017 , ' North Fennoscandian mountain forests : History, composition, disturbance dynamics and the unpredictable future ' , Forest Ecology and Management, vol. 385 , pp. 140-149 . https://doi.org/10.1016/j.foreco.2016.11.031

http://hdl.handle.net/10138/175972

https://doi.org/10.1016/j.foreco.2016.11.031

acceptedVersion

Downloaded from Helda, University of Helsinki institutional repository.

This is an electronic reprint of the original article.

This reprint may differ from the original in pagination and typographic detail.

Please cite the original version. 
1 North Fennoscandian mountain forests: History, composition, disturbance

2 dynamics and the unpredictable future

3

4

5

6 Timo Kuuluvainen ${ }^{1 *}$, Annika Hofgaard ${ }^{2}$, Tuomas Aakala ${ }^{1}$ and Bengt Gunnar Jonsson ${ }^{3}$

$7 \quad{ }^{1}$ Dept. of Forest Sciences, University of Helsinki, Finland

$8{ }^{2}$ Dept. of Terrestrial Ecology, Norwegian Institute for Nature Research, Norway

$9{ }^{3}$ Dept. of Natural Sciences, Mid Sweden University, Sweden

10

*Corresponding author

11

Keywords: Biodiversity, Boreal forest, Climate change, Cultural heritage, Natural disturbance,

13 Northern Europe 


\section{ABSTRACT}

North Fennoscandian mountain forests are distributed along the Scandes Mountains between Sweden and Norway, and the low-mountain regions of northern Norway, Sweden and Finland, and the adjacent northwestern Russia. Regionally, these forests are differentiated into spruce, pine or birch dominance due to climatic differences. Variation in tree species dominance within these regions is generally caused by a combination of historical and prevailing disturbance regimes, including both chronic and episodic disturbances, their magnitude and frequency, as well as differences in edaphic conditions and topography. Because of their remoteness, slow growth and restrictions of use, these mountain forests are generally less affected by human utilization than more productive and easily utilizable forests at lower elevations and/or latitudes. As a consequence, these northern forests of Europe are often referred to as "Europe's last wilderness", even if human influence of varying intensity has been ubiquitous through historical time. Because of their naturalness, the North Fennoscandian mountain forests are of paramount importance for biodiversity conservation, monitoring of ecosystem change and for their sociocultural values. As such, they also provide unique reference areas for basic and applied research, and for developing methods of forest conservation, restoration and ecosystem-based management for the entire Fennoscandia. However, the current rapid change in climate is predicted to profoundly affect the ecology and dynamics of the se forests in the future. 


\section{Introduction}

North Fennoscandian mountain forests are distributed along the remains of ancient mountain ranges, most notably the Scandes mountain range along the border between Sweden and Norway, and the low-mountain regions of northern and northeastern Finland, and the adjacent northwestern Russia (Fig. 1). These regions harbor both northern boreal forests and subarctic/subalpine birch forests, which are collectively henceforward referred to as northern mountain forests. Because of remoteness, low productivity and restrictions of use, the overall human impact on these forests has generally remained significantly lower compared with more southern boreal forests at lower latitudes and/or elevations (Veijola, 1998). However, over the entire region, some low-intensity human use of the forest has occurred for millennia, such as the influence of the Sápmi people and their reindeer herding culture (Josefsson et al., 2009). Reindeer herding continues to be a culturally important land use, which has recently also generated conflicts with other land uses like forestry (Helle and Jaakkola, 2008; Berg et al., 2008).

The exact degree of human impact, i.e. the extent to which the current forests deviate from a natural state, varies strongly across forest types and landscapes, from negligible to local deforestation (Östlund et al., 2015). Nevertheless, these mountain forests still harbor some of the largest areas of relatively natural boreal forest in Northwestern Europe (Aksenov et al., 2014). By natural forest we mean a forest which structure, species composition and processes have not been significantly altered by human activities (Brumelis et al. 2011). Much of our current understanding of natural forest disturbance and successional dynamics and their impact on biodiversity in Fennoscandian conditions is derived from these forests (Kuuluvainen and Aakala, 2011). The ongoing climate change, 
with a predicted mean annual increase of mean annual temperature by $4^{\circ} \mathrm{C}$ and precipitation by $20 \%$ by the end of the $21^{\text {st }}$ century (IPCC, 2013), is likely to profoundly affect the ecology, dynamics and productivity of these forests in the future (Kellomäki et al., 2008; IPCC, 2013; Gauthier et al., 2015).

The ecological character and biological diversity of northern mountain forests reflect to a large extent their Holocene climate and vegetation history. Because of their northern position, continental ice retreated from these areas as late as around $15-10000$ years before present (Parducci et al., 2012). Tree species colonized the region from different directions, following the course of retreat of the ice sheet. The developing early Holocene tree communities were accordingly characterized by the forests surviving the glaciation period and surrounding the retreating ice to the west, south and east (Kullman, 2008; Paus et al., 2011; Parducci et al., 2012). Current dominant boreal tree species, pine (Pinus sylvestris L.), spruce (Picea abies (L.)Karst.) and birch (Betula pubescens Ehrh.), all arrived in early Holocene 14-11 kyr B.P in the first de-glaciated areas of western Fennoscandia (Kullman, 2008). During the mid-Holocene climatic optimum, thermophilous deciduous tree species like elm and oak occurred in the region.

The historic timing of formation of boreal tree species dominance at stand or regional scales differs between species, with birch and pine predating spruce (Kullman, 2008). The spread and development of regional dominance of spruce has occurred in the last ca. 3000 years, in parallel with long-term climate changes favoring spruce but disfavoring thermophilous tree species (Kullman, 2001; Giesecke and Bennett, 2004; Bradshaw and Lindbladh, 2005). Concurrently with increasing spruce dominance, high elevation and high latitude forests retreated downhill and southwards (Payette and Lavoie, 1994; Kullman, 1995). This process was reversed after the termination of the Little Ice Age (Grove, 1988) in 
late $19^{\text {th }}$ century. The rate of this recent regain of forest area differs somewhat between geographical regions and between tree species, but has generally accounted for ca. 0.6 vertical meters per year in the northeastern part of the mountain forest region (Aakala et al., 2014; Mathisen et al., 2014) and 0.9 vertical meters per year in the southern part (Kullman and Öberg, 2009). Latitudinal advance has occurred with ca. $150 \mathrm{~m}$ per year for birch forest and ca. $70 \mathrm{~m}$ per year for pine forests (Hofgaard et al., 2013).

The impact of climate change on forests close to their bioclimatic range limits entail a complex web of both gradual and episodic abiotic and biotic processes (Hofgaard, 1997;

Scheffer et al., 2012). The warming climate changes ecosystem structure and composition through changing competitive relationships among the constituent tree species (Kellomäki et al., 2008). Climatic conditions are changing too fast for long-lived plant species such as trees to respond through natural migration, and this is predicted to increase the probability and severity of disturbance events. In addition other change rate-related developments, such as extreme weather events and insect outbreaks are likely to become more common (IPCC, 2013; Gauthier et al., 2015). These perturbations could counteract or reinforce climatedriven changes of the northern mountain forest ecosystems (Hofgaard, 1997; Koven, 2013; Bright et al., 2014). There are historical and modern examples where perturbations, such as cuttings, forest fires or insect outbreaks have pushed northern mountain forest ecosystems to an alternative, non-forested stable state (e.g. Neuvonen et al., 2005; Karlsson et al., 2009; Östlund et al., 2015).

A large share of the remaining natural Fennoscandian mountain forests are protected. These forests together with other forests with long history of low human interference and restrictions of utilization, have provided unique possibilities for fundamental research on the ecology of primeval forests at various scales (Kuuluvainen and 
Aakala, 2011). Thus, much of our current understanding of natural forest disturbance and successional dynamics, and biodiversity concerning Fennoscandian boreal forests as a whole is derived from these northern mountain forests.

The main purpose of this paper is to review the current understanding of the dynamics and disturbance ecology of North Fennoscandian mountain forests and to discuss the implications of this knowledge on forest conservation, restoration and ecosystem-based management in the context of ongoing climate change. Specifically, we asked: 1) What is the value of understanding of past ecosystem dynamics considering future conditions? 2) How resilient are the mountain forests in a changing environment? 3) What are the main shortcomings of knowledge concerning the ecology of mountain forests? 4) What are the main lessons learned from ecological research concerning conservation and ecosystem based management?

\section{Definition, geographic distribution, environmental conditions and forest communities}

Due to the location of the region at high latitudes, forests considered as mountain forests are growing at lower elevations than elsewhere in Europe. Hence, we loosely define northern mountain forests as those prevailing in the mountainous region and growing close to the elevational and latitudinal limit of forest distribution. However, tree line areas are excluded from this review. Forest is defined as a tree community with minimum tree height of $5 \mathrm{~m}$ and at least $10 \%$ of canopy cover (FAO, 2010).

In this paper North Fennoscandian mountain forests are defined to stretch latitudinally from southern Swedish Lapland at $64^{\circ} \mathrm{N}$ to $69^{\circ} \mathrm{N}$ in northern Norway, and longitudinally from $14^{\circ} \mathrm{E}$ in Norway to $34^{\circ} \mathrm{E}$ in the Kola Peninsula, Russia (Fig. 1). In the west, the Scandes Mountains rise to height of $1000-2100 \mathrm{~m}$ above sea level (a.s.l.). The area east of the northern Scandes Mountains through northern Finland and to Kola Peninsula is 
141 characterized by gently rolling hills (fells), which rarely reach heights above $1000 \mathrm{~m}$ a.s.l.. The

142 bedrock in the area is mostly composed of ancient Precambrian granites and gneisses,

143 covered by Quaternary and younger Holocene sediments, mainly podzolized moraines

144 (Lidmar-Bergström and Näslund, 2005).

145 North Fennoscandian mountain forests are unique in that, due to the warming effect of the 146 golf-stream, they grow further north than any other mountain forests. Compared to more

147 southern mountain forests, the light climate is characterized by stronger seasonal changes,

148 with long days in the summer and several months of short days in the winter. The extreme

149 annual variation in solar radiation is reflected in below-zero temperatures and snow cover

150 which prevail for 7-8 months. Also, low sun angles are prevalent for part of the growing

151 season, which emphasizes the effect of topography on the distribution of solar energy, e.g.

152 on south vs. north facing slopes.

153

The climatic differences within the region are further shaped by the location between

154

155

156

157

158

159

160

161

162

163

164

the Atlantic and Arctic oceans, and the Eurasian continent. The climate ranges from

markedly or slightly oceanic close to the Norwegian coast (Moen, 1999), to variably

continental in different areas of central and eastern parts of northern Fennoscandia. This

gives rise to large differences in precipitation, which varies from $1000 \mathrm{~mm}$ in the western

part to $450-500 \mathrm{~mm}$ in northern Finnish Lapland and $300-400 \mathrm{~mm}$ in more continental parts of northern Norway and Sweden (Moen, 1999; Tikkanen, 2005). A considerable share of the precipitation falls as snow during the winter months.

Although mixed stands also occur, forests are regionally differentiated into spruce, pine or birch dominance due to topography and edaphic conditions and climate regimes. In general, xeric sites are dominated by pine, while mesic sites follow a post-disturbance successional trajectory from birch as a pioneer species, to the dominance of spruce. At 
smaller-scales and on sites capable of supporting any of the three main species, tree species dominance is influenced by within-region characteristics and variation in the disturbance regimes.

In general, North Fennoscandian mountain forests can be considered as among the last remnants of natural forests in Europe. Here we adopt the view of naturalness described by Brumelis et al., (2011) which puts focus on structures, species and processes as the three core dimensions of forest naturalness. For a large part of the Fennoscandian mountain forests, trees of all species and wide age ranges occur, volumes of dead wood, species richness among plants, fungi and animals are high and natural disturbance processes are still active. As a large fraction of boreal forest species in general are dependent on dead wood (Stokland et al., 2012), the mountains forests represent important core area for many species declining elsewhere in Fennoscandian boreal forests.

\subsection{Scots pine dominated forests}

Scots pine dominated forests in North Fennoscandia often occur on rocky or dry sandy and moraine soils, on glaciofluvial soils, on eskers and on delta formations (Raunio et al., 2008). These forests are generally open and exhibit signifigant variability in structure and successional stages as well as small-scale spatial heterogeneity (Aaltonen, 1919). In spite of their openness, belowground competition plays a major role in tree regeneration and stand dynamics (Kuuluvainen and Ylläsjärvi, 2011). Mixed-severity fires have historically been one driver of forest dynamics (Aaltonen, 1917; Hesselman, 1917), although fire cycles have been longer than previously assumed, up to hundreds of years (Wallenius et al., 2010). Even nonpyrogenic pine dominated forests exist, but at a low frequency (Zackrisson et al., 1995). 
Species dominating the forest floor include dwarf shrubs Calluna vulgaris, Vaccinium vitisidaea and Empetrum hermaphroditum, and in the bottom layer mosses and lichens such as Pleurozium schreberi, Cladonia arbuscula and C. rangiferina.

The degree of naturalness has been declining during recent decades particularly in the pine dominated lichen-rich forests in many regions of the mountain forests. For example, in northern Finland, this is associated with factors such as reduction of old forests due to forestry, and increasing trampling and grazing by reindeer which accelerate nutrient cycling (Raunio et al., 2008). In addition, although fire cycles tend to be long in these northern pine forests (see below), the century long fire suppression represent loss of naturalness (Drobyshev et al., 2014).These factors are also likely future threats to this habitat type, in addition to effects of climate change (Gauthier et al., 2015).

A prominent feature in natural pine forests is the presence of large standing dead and bark-less snags, so called kelo trees (sensu Niemelä et al., 2002, Fig. 2a). These trees have commonly survived a history of repeated surface fires, and hence their wood has a characteristic high resin content, and are thus highly resistant to decay (Niemelä et al., 2002). As such they represent in some cases a forest structure developing over millennia - as living trees for more than 500 years, and as snags for up to several centuries, before finally falling to the ground and slowly decomposing.

\subsection{Norway spruce dominated forests}

Norway spruce dominated forests cover extensive areas in North Fennoscandian Mountains. These forests are found on mesic to moist sites with varying fertility from productive herb-rich sites to poorer site where mosses and dwarf shrubs (predominantly 
Vaccinium myrtillus L.) dominate the forest floor, and accumulation of poorly decomposed

214 raw humus is prominent (Fig. 2b, Arnborg, 1943; Havas and Kubin, 1981). As fire is rare in Norway spruce dominated forests (Hörnberg et al. 2011; Ohlson et al. 2011), late successional forest dynamics is characterized by gap or patch scale disturbances and regeneration (Hofgaard 1993 a, b; Edman et al., 2007; Aakala and Keto-Tokoi, 2011).

Disturbance agents often include wind in combination with fungal infections, insects and snow (Edman et al., 2007; Lännenpää et al., 2008). A prominent feature among dying spruce is a general senescence prior to mortality, with either persistent slow growth or steadily declining growth in the decades preceding their deaths (Fraver et al. 2008; Lännenpää et al., 2008).

In the spruce dominated forests the establishment of tree seedlings is often physically impeded by the ubiquitous mat of dwarf shrubs, grasses, mosses and a layer of poorly decomposed humus, which decreases nutrient availability (Arnborg, 1943; Sirén, 1955). Hence regeneration is strongly dependent on the availability of suitable substrates created by local gap or patch disturbances, such as mineral soil exposed by tree falls and uprootings, and decaying logs on the forest floor (Hofgaard, 1993a, b; Hörnberg et al. 1997; Caron et al., 2009; Grenfell et al., 2011). For spruce, individual decaying logs may remain important regeneration substrate for as long as 150 years (Hofgaard, 1993a). This long-term suitability of logs as regeneration substrate counter balance the low frequency production of viable seeds, with good seed years occurring typically many years apart (Hofgaard, 1993c). Spruce may also reproduce vegetatively through layering and form long-lasting clones (Öberg and Kullman, 2011). This is in particular a characteristic in abiotic harsh environments such as the forest-tundra transition and in coastal areas. Overall, the diversity of microsites 
created by tree falls provide opportunities for recruitment of other tree species in addition to spruce.

Accordingly, late successional spruce forest generally maintain some proportion of birch admixture (Steijlen and Zackrisson, 1987).

Forest fires are rare in spruce-dominated forests (Ohlson et al. 2011), due to the low flammability of the thick humus layer, which retains moisture for extended periods of time (Tanskanen et al., 2005). However, when conditions are beneficial for forest fires to occur, their impact on forest is usually drastic (Wallenius et al., 2005). This is due to the combination of thin poorly insulating bark and low-hanging branches that create ladder-fuels and promote crown scorching and even crown fires. As a result, spruce trees are easily killed by fire creating a huge amount of dead wood. The post-fire succession usually starts with dominance of deciduous species, mainly birch but also aspen (Populus tremuloides) and goat willow (Salix caprea L.) (Sirén, 1955). Hence, similar to wind-throws, forest fire support the presence of deciduous species as an important tree component in otherwise spruce dominated landscape.

\subsection{Mountain birch dominated forests}

At sites edaphically and climatically suitable for the two conifers, abundance of birch is a characteristic of a transient early-successional stage. However, elsewhere mountain birch dominated forests cover large areas of Northern Fennoscandia (Fig. 2c). The main part of this ecoregion is mainly located in Norway, followed by Sweden and to a lesser extent in Finland and the Kola Peninsula in Russia. These forests characterize the landscape both in coastal and inland areas at elevations and latitudes above and beyond the coniferous boreal 
forest. In birch-dominated subalpine and subarctic areas, mountain birch is usually referred

261

262

263

264

265

266

267

268

269

270

271

272

273

274

275

276

277

278

to at subspecies-level (B.p. ssp tortuosa Ledeb. or B.p. ssp czerepanovii (Orlova) Hämet-Ahti are most common in the literature). When it occurs in other areas in mixture with the coniferous boreal trees, it is generally referred to at species-level, i.e. B. pubescens.

The mountain birch has a wide bioclimatic range, and species composition of the forest floor varies accordingly. Dwarf shrubs (Vaccinium spp., Empetrum sp.) are generally most abundant, but herb-rich communities prevail in humid nutrient-rich areas and lichen dominated communities in dry areas. In Norway and Sweden, where reindeer herding is associated with rotation of grazing areas, lichen dominated inland areas are commonly used as winter grazing lands for semi-domesticated reindeer, while herb-rich birch forests are used as summer grazing lands. During the last decades the lichen biomass has decreased due to intense grazing practice, and is being replaced by moss-rich communities (Tømmervik et al., 2009).

Natural birch forest dynamics is driven by cyclic and abrupt population increases of defoliating insects, such as the autumnal moth (Epirrita autumnata) and winter moth (Operophtera brumata) (Tenow, 1972; Tenow et al., 2007). The frequency and intensity of these insect outbreaks are linked to climate at local to regional scales, and can cause large scale stand mortality (Fig. 2d, Tenow and Nilssen; 1990; Neuvonen et al., 2005; Tenow et al., 2007). Following the defoliation and subsequent stem mortality, the birch forest will slowly recover its density through mainly growth of basal sprouts (Tenow, 1996; Tenow and Bylund, 2000). Mountain birch has both frequent and high quality seed production throughout its range, as opposed to spruce and pine, and recruitment is not seed limited. However, grazing and browsing animals such as sheep in Norway, and reindeer throughout the region might hinder tree recruitment and maintain open woodland areas (Aune et al., 2011). 


\section{Disturbance and successional dynamics}

The accumulated body of information challenges the conventional view that North

Fennoscandian mountain forests mostly represent homogeneous and static communities of the 'climax type'. The development of forests is slow indeed, because they grow in harsh climatic conditions in the proximity of the range limits of the constituent tree species.

However, these forest ecosystems are in a state of constant change even in the absence of major disturbances (Lilja et al., 2006; Edman et al., 2007; Caron et al., 2009; Aakala et al., 2009).

The disturbance agents in mountain forest landscapes vary greatly in their type, severity and spatio-temporal characteristics. Some disturbance factors, such as fires (Kauhanen, 2002; Vajda et al., 2006), storms (Aakala et al., 2009), snow load (Hesselman, 1912; Hofgaard et al., 1991) and insect outbreaks (Tenow et al., 2013), are occasionally capable of causing widespread mortality, whereas some operate at smaller scale but more frequently such as pathogenic fungi and browsing/grazing mammals (e.g. moose and reindeer) (Edman et al., 2007; Lännenpää et al., 2008), and sometimes snow and slush avalanches, which occasionally reach into forested areas (Fig. 2e). Taken together these multi-cause disturbances act as diversity drivers at a wide range of spatial and temporal scales. (Kuuluvainen, 2009). Two of them are classical modes of forest dynamics: even-aged stand dynamics driven by stand-replacing disturbance, and gap or patch phase dynamics driven by small scale tree mortality mostly in old forests. However, as the review of Kuuluvainen and 
Aakala (2011) highlights, intermediate severity disturbances, causing partial tree mortality and leading to complex stands structures consisting of multiple tree age cohorts, are also common (Lassila, 1921; Hofgaard, 1993a). In reality, these types of forest dynamics can be mixed in space and time and are thus not easily separable even at stand scale.

At landscape scale, these different disturbance factors and the associated dynamics often operate in a mixed or nested manner in space and time. More or less continuously occurring deaths of individual or small groups of trees (gap dynamics) (Kuuluvainen, 1994) often appear superimposed on the more infrequent but larger scale partial disturbance events due to insects, wind or fire (Fraver et al., 2008). This kind of disturbance regime that operates at multiple spatial and temporal scales typically creates variable and complex forest structures (Caron et al., 2009).

In the boreal forest, fire is traditionally considered as the dominating disturbance agent (Sirén, 1955; Zackrisson, 1977). In Fennoscandian mountain forests, however, fire has played a smaller role compared to boreal forest at lower elevations and latitudes. This is due to both natural and anthropogenic reasons: these areas show a short fire season due to high precipitation and late snow melt, and the decreasing lightning frequency towards north translate into reduced natural ignitions (Granström, 1993; Larjavaara et al., 2005). In addition, the formerly important anthropogenic driver of ignitions has generally become weaker, especially during the $20^{\text {th }}$ century (Wallenius, 2011). Accordingly, fire history studies using tree rings or cores from peatlands and lake sediments, have shown that prior to significant human influence the fire cycles were in the range of several hundred years (Carcaillet et al., 2007; Wallenius et al., 2010). However, despite fires being rarer than in the southern parts of the boreal forests (Granström, 1993; Larjavaara et al., 2005; Drobyshev et al., 2014), their influence is readily apparent in the age structure and species composition at 
xeric sites (Lassila, 1921), and in many places these sites still display structures typical for surface-fire driven dynamics (Kuuluvainen and Aakala, 2011).

Compared with xeric pine dominated forests, the fire cycles have been longer in moister Picea abies dominated forests, and it is possible that parts of northern mountain forests have not burned since the last glaciation (Hyvärinen and Sepponen 1988; Steijlen and Zackrisson, 1987; Fraver et al., 2008). The intrinsically long fire cycles in the spruce-

dominated Fennoscandian mountain forests indicate that other disturbance agents than fire play an important role in forest dynamics (Norokorpi, 1979; Hofgaard, 1993; Kuuluvainen and Aakala, 2011). In the absence of fire, tree mortality is caused by wind, competition, fungi, insects and stem breakage due snow loads (Hofgaard et al., 1991; Lännenpää et al., 2008), disturbances which are often related to old age and senescence of trees (Fraver et al., 2008). This type of tree mortality agents drive gap phase dynamics resulting in small-scale heterogeneity of forest structure, characterizing both age- and physiognomic structure, in these old growth spruce forests (Hofgaard 1993a,b, Caron et al. 2009). These small-scale gap dynamics result in a fairly constant background mortality that is then occasionally punctuated with episodic larger scale disturbances, especially storms (Jonsson and Dynesius, 1993; Kuuluvainen, 1994; Fraver et al., 2008; Aakala et al., 2009). Disturbances such as wind throws expose mineral soil promoting regeneration, and allowing deciduous trees to maintain their presence in otherwise conifer-dominated stands over the longer term in particular (Kuuluvainen, 1994; Grenfell et al., 2011), as well as supporting diversity in the ground vegetation (Jonsson and Esseen, 1990).

Forest fires are relatively rare in mesic sites in northern mountain forests, but under favourable conditions, they can be severe and affect large areas (Kauhanen, 2002; Aakala et al., 2009). An example is provided by the northern spruce forest studied by Aakala et al. 
(2009) which was still dominated by the post-fire tree cohort regenerated following a fire 317 years earlier. Such stand-replacing fire events have a significant and long lasting impacts on forest landscape structure, composition and biodiversity (Yli-Sirniö et al., 2012). Standreplacing fires create open sunny habitats with large amounts of charred dead wood, which harbour a high number of saproxylic species, many of which were earlier thought to be confined to shady and moist old-growth forests (Martikainen, 2000). On fertile soils and mesic conditions the successions following fire are first dominated by deciduous species, such as Betula spp., Populus tremula and Salix caprea (Sirén, 1955; Lilja et al., 2006). Later in succession deciduous tree species give way to Picea abies which gains increasing dominance. However, Betula, Populus and Salix trees may remain as a component of the forest for long time periods due to their ability to produce asexual sprouts from the base (Betula and Salix) and the roots (Populus). In particular, this asexual reproduction ability is essential to birch forest recovery after both stand-level and landscape-level insect outbreaks (Tenow, 1996; Tenow and Bylund, 2000). Seed-based recruitment is prohibited or delayed by grazing and field layer competition (Tenow, 1996). The presence of Populus and Salix have important biodiversity consequences since they host a large number of specialized species (e.g. Martikainen, 2000; Kuusinen, 1996).

Although the effect of competition on forest dynamics may be less pronounced than in more productive forests at lower latitudes (Hytteborn et al., 1987) due to the open structure of mountain forests (see Fig. 2), competition may still be a factor regulating tree growth and mortality (Kuuluvainen and Ylläsjärvi 2011). For instance, Aakala et al. (2016) showed that competition clearly influenced the asymmetry of tree crowns, and Fraver et al. (2013) showed that the spatial arrangement of trees within stands regulated inter-tree competition and tree growth in old-growth mountain spruce forest. This latter is further 
exemplified by distinct growth releases of neighboring trees when single trees die (Dynesius and Jonsson, 1991; Caron et al., 2009).

In the big picture of spatio-temporal forest dynamics, different variations of unevenaged (or cohort-aged) dynamics appear to play a dominant role in Fennoscandian mountain forest dynamics. In Picea dominated stands occurring on moist sites this is due to absence of fire and thus inherently long fire rotations (Wallenius et al., 2010) and the predominance of gap or patch dynamics. In dry Pinus dominated sites, where fires may be more common, tree mortality is often partial or patchy as large Pinus trees with their thick heat-insulating bark often survive surface fires. This, and the post-fire regeneration, result over time in forest with several age cohorts of trees (Lassila 1921; Engelmark et al., 1998). In Betula dominated forests insect outbreaks are, in the absence of fire, the main driver of stand dynamics.

\section{Discussion}

$$
\text { understanding of the history, ecology, biodiversity and dynamics of North Fennoscandian }
$$
mountain forest ecosystems, and the varying but ubiquitous long-term influence of humans on these seemingly natural forest ecosystems (Fraver et al., 2008; Josefsson et al., 2009; Kuuluvainen and Aakala, 2011). It is clear that the predicted rapid changes in climate will greatly influence many key biological processes controlling the dynamics of these forests growing close to their northern distribution range. Some of the changes are gradual but also episodic more drastic disturbances will become more likely (Gauthier et al. 2015). As a consequence, the ongoing climate change will exert unprecedented pressures to the "health" of these forests, which are of paramount importance as biodiversity hotspots and 
as the core of the forest protection area network in the whole of Fennoscandia. Critical components of ecosystem health can be defined as the biodiversity, resilience and adaptive capacity of the constituent ecosystems (Gauthier et al., 2015). These ecosystem properties are the crucial components of forest health and should form the basis of conservation and management actions.

Our understanding of the ecology and dynamics of these forests is based on past conditions. A relevant question then is how relevant and useful this knowledge is in the future climatic conditions that will significantly differ from past conditions (Sprugel, 1991; Keane et al., 2009; IPCC, 2013). However, we can identify several important roles that research on past disturbance dynamics can play in forest protection and sustainable ecosystem-based management. First, an often-invoked role is the establishment of baseline or reference information on ecosystem properties and dynamics (e.g. natural range of variability, Willis and Birks, 2006; Keane et al. 2009). Detecting changes is possible only if we have a sufficient understanding of the baseline conditions and their variability. Second, we need knowledge on past forest dynamics to understand how the baseline conditions have historically formed and, for example, what has been the role of human activities in this process (Hofgaard, 1999; Josefsson et al. 2009).

Given that humans have lived in the Fennoscandian mountain forests for millennia we can assume that they to some extent have influenced forest structure and dynamics (e.g. Östlund et al. 2004). Prior to colonization by mainly farmers from the south during the $17^{\text {th }}$ and $18^{\text {th }}$ centuries, only indigenous Sami groups lived in these forests. Sami people have traditionally been viewed as finding subsistence from hunting and gathering and relatively late in history becoming dependent on reindeer herding (see Sommerseth 2010). However, the traditional view is being challenged and no consensus on the onset of reindeer herding 
seems to exist. Also recent studies suggest that Sami land-use was more complex than assumed and may have included small scale shifting cultivation (Östlund et al. 2015). The land use pattern is evident in pollen profiles from local settlements and provide together with archeological evidence an insight in to Sami subsistence patterns (Sommerseth 2010). It is suggested that in some place forest resources may have been overexploited near the tree line, resulting in ecosystem degradation and subsequent shift in land use (Bergman et al. 2013). However, in general it is difficult to translate the impact of Sami land use into a broader impact on the forest landscape.

Understanding the historical processes is a pre-requisite for appropriate use of the past baseline information. For example, in research on forest change over larger spatial scales, using satellite images and forest inventories, past forest dynamics need to be understood to attribute detected changes to effective drivers. This is necessary to discern the influences of past disturbances from the direct influences of climate change due to warming temperatures, increasing $\mathrm{CO}_{2}$ concentration or nitrogen deposition (Myneni et al. 2001). Another prerequisite for effective monitoring is looking at deviations from baseline conditions at multiple spatial scales.

North Fennoscandian mountain forests are occasionally considered to be resilient against adverse changes, particularly because a large part of them is protected (Aksenov et al. 2014). This view may also gain support from the slow growth and sometimes quasiequilibrium dynamics of late-successional forests (e.g. Caron et al., 2009; Aakala et al., 2009). However, we have learned that these forests are not as stable as was perhaps once assumed and ecological theory predicts that ecosystems close to their distribution range are most vulnerable to sudden state shifts (Atkinson, 1992; Scheffer et al., 2012). For instance, the 
Holocene history tells us that major changes in altitudinal positions in the treeline ecotone may occur as a result of the predicted changes in future climate (Aakala et al. 2014).

It is generally acknowledged that climate change will strongly affect the future development of forests and the predicted temperature increase (IPCC 2013) suggest that the climate conditions in mountain forests will be displaced towards conditions resembling forests at lower altitudes. It is also clear that disturbance is central in vegetation dynamics and in translating climate change into vegetation response (Overpeck et al., 1990). There is a risk that with accumulating environmental stressors in the rapidly warming climate, critical thresholds are surpassed and abrupt changes in ecosystem conditions can become a reality (Gauthier et al. 2015). Old spruce forests are perhaps most vulnerable to the effects of warming climatic conditions and associated disturbances such as droughts, insect outbreaks, and perhaps also fire (Kellomäki et al., 2008; Kuuluvainen et al. 2014).

However, we lack understanding of the changing role of disturbances, and especially that of fire in mountain forest ecosystems. In the past centuries, the occurrence of fire has to a great extent been determined by human influences in interaction with those of climatic fluctuations (Drobyshev et al., 2014). First, settlement activities until late $20^{\text {th }}$ century increased fires due to human-caused ignitions. Since forests became a valuable resource, fire was handled more carefully and fire suppression was developed, which resulted in an almost-complete elimination of forest fires over the entire Fennoscandia (Wallenius, 2011; Drobyshev et al., 2014). This was true also in xeric sites where fires have historically been most prevalent. As trees are long-lived, the lack of fire manifests itself gradually, but eventually leads to changes in structure and composition in forests previously shaped by fires. For example, pine regeneration may be impeded while fire-sensitive spruce may gain dominance especially on more moist and fertile sites capable of supporting spruce (Linder et 
al. 1997; Sutinen et al., 2005). The absence of fire is also reducing the occurrence of early successional deciduous forest in the landscape and the regeneration possibilities for rare biodiversity-maintaining pioneer tree species, such as Salix caprea. A climate-induced broadening of the distribution of defoliating insects, such as Epirrita autumnata, may potentially hasten this development through reduction of deciduous mixture in coniferdominated mountain forests (Jepsen et al., 2008).

However, predicting the future development of complex ecological systems and their disturbance dynamics is difficult (Messier et al., 2014). In particular, we lack knowledge of possible ecological thresholds of different kinds of mountain forest ecosystems to changing environmental factors, stressors and disturbances. An important question is the interaction of different disturbance factors in a warming climate. We can qualitatively predict, for example, that increased tree mortality due to abiotic factors such as wind or droughts can increase biotic damages (e.g., due to bark beetles) (Kuuluvainen et al., 2014). However, quantitative prediction is difficult because of the unknown ecosystem thresholds and stochastic nature of climate-driven disturbance phenomena, increasing the possibility of unexpected events and surprises (Scheffer et al. 2014). These uncertainties, and the notion that climate change will manifest itself earlier in ecosystems at climatic margins, calls for increasing monitoring of the mountain forest ecosystems.

The North Fennoscandian mountain forests are of paramount importance as biodiversity hotspots, for monitoring of environmental change, and as a reference for forest restoration and ecosystem based management (Kuuluvainen and Aakala, 2011; Halme et al., 2013). They also have a rich cultural heritage. Northern mountain forests are important for the indigenous Sápmi people and their reindeer herding culture. However, there is a history of conflicts between reindeer herding and logging activities especially in Finland (Helle and 
Jaakkola, 2008) and Sweden (Berg et al., 2008), and there will possibly be increasing pressure

500

501

502

503

504

505

506

507

508

509

510

511

512

513

514

515

516

517

518

519

520

521 for timber harvesting in the so far unprotected mountain forests. New economically important and rapidly increasing land uses affecting mountain forests are nature-based tourism and mining. This complex development and potential conflicts between different competing land uses, highlight the need for conservation and ecologically sustainable management based on adequate understanding and prediction of future trajectories of mountain forest ecosystems.

Then what could be the main lessons learned from ecological research in North Fennoscandian mountain forests concerning conservation and ecosystem-based management? A major conclusion to be drawn from the ecological research literature is that fine scale processes of disturbance and regeneration, and long-term continuity of structural characteristics are essential features of mountain forests and their dynamics. These are also the ecosystem characteristics and their historical range or variability, which need to be respected if biomass harvesting is considered. However, it could be argued that the main value of the remote and slow-growing Fennoscandian mountain forests is not as a biomass resource. Instead they harbor significant values related to cultural heritage, tourism and recreation, biodiversity, and serving as reference monitor of the effects of climate change in marginal forest ecosystems.

\section{Acknowledgements}

We thank the Academy of Finland project Ecological history and long-term dynamics of the Boreal forest ecosystem (EBOR, project no. 276255) and the Research Council of Norway (grant no. 160022/F40) for financial support. The current paper is also to be seen as a results 
its Nordic Forest Research (SNS) cooperation body)

524

525

526

527

528

529

530

531

532

533

534

535

536

537

538

539

540

541

542

543

544

545

546

547

548

549

550

551

552

553

554

555

556

557

558

559

560

561

562

563

564

\section{References}

Aakala, T., Kuuluvainen, T., Wallenius, T., Kauhanen, H., 2009. Contrasting patterns of tree mortality in late-successional Picea abies stands in two areas of northern Fennoscandia. J. Veg. Sci. 20, 1016-1026.

Aakala, T., Keto-Tokoi, P., 2011. The old Norway spruce forests of northern boreal Fennoscandia are alive and well: A review of Sirén (1955). Scand. J. For. Res. 26 (Suppl 10), DOI: 10.1080/02827581.2011.517942.

Aakala, T., Hari, P., Dengel, S., Newberry, S.L., Mizunuma, T., Grace, J., 2014. A prominent stepwise advance of the tree line in north-east Finland. J. Ecol. 102, 1582-1591.

Aakala, T., Shimatani, K., Abe, T., Kubota, Y., Kuuluvainen, T., 2016. Crown asymmetry in high latitude forests: disentangling the directional effects of tree competition and solar radiation. Oikos 125, 1035-1043, DOI: 10.1111/oik.02858

Aaltonen, V.T., 1919. Über die naturliche Verjungung der Heidewälder im finnischen Lappland (in Finnish with German summary). Commun. Inst. Quaest. For. Finlandiae Editae 1, $319 \mathrm{p}$.

Aksenov, D., Kuhmonen, A., Mikkola, J., Sobolev, N. (eds.), 2014. The characteristics and representativeness of the protected area network in the Barents region. Report 29 Finnish Environment Institute, Helsinki, Finland.

Arnborg, T., 1943. Granberget - en växtbiologisk undersökning av ett sydlappländskt granskogsområde med särskild hänsyn till skogstyper och föryngring. Norrländskt handbibliotek 14. (In Swedish with German summary).

Atkinson, D., 1992. Interactions between climate and terrestrial ecosystems. Trends Ecol. Evol. 7, 363-365.

Aune, S., Hofgaard, A., Söderström, L., 2011. Contrasting climate and land use driven tree encroachment pattern of sub-arctic tundra in Northern Norway and Kola Peninsula. Can. J. For. Res. 41, 437-449.

Berg, A., Östlund, L., Moen, J., Olofsson, J., 2008. A century of logging and forestry in a reindeer herding area in northern Sweden. For. Ecol. Manage. 256, 1009-1020

Bergman, I., Liedgren, L. Zackrisson, O. 2013. From hunting to herding: Land use, ecosystem processes, and social transformation among sami AD 800-1500. Arctic Anthropology 50:25-39

Bradshaw, R.H.W., Lindbladh, M. 2005. Regional spread and stand-scale establishment of Fagus sylvatica and Picea abies in Scandinavia. Ecology 86(7): 1679-1686

Bright, R.M., Antón-Fernandez, C., Astrup, R., Cherubini, F., Kvalevåg, M., Strømman, A.H., 2014. Climate change implications of shifting forest management strategy in a boreal forest ecosystem of Norway. Global Change Biology 20, 607-621.

Brumelis, G., Jonsson, B.G., Kouki, J., Kuuluvainen, T., Shorohova, E. 2011. Forest naturalness in northern Europe: Perspectives on processes, structures and species diversity. Silva Fenn. 45(5), 807-821. 
Carcaillet, C., Bergman, I., Delorme, S., Hörnberg, G., Zackrisson, O., 2007. Long-term fire frequency not linked to prehistoric occupations in northern Swedish boreal forest. Ecology 88(2), 465-477.

Caron, M.-N., Kneeshaw, D.D., De Grandpre, L., Kauhanen, H., Kuuluvainen, T., 2009. Canopy gap characteristics and disturbance dynamics in old-growth Picea abies stands in northern Fennoscandia: Is the forest in quasi-equilibrium? Ann. Bot. Fenn. 46, 251-262.

Drobyshev, I., Granström, A., Linderholm, H.W., Hellberg, E., Bergeron, Y., Niklasson, M., 2014. Multi-century reconstruction of fire activity in Northern European boreal forest suggests differences in regional fire regimes and their sensitivity to climate. J. Ecol. 102,738-748, doi: 10.1111/1365-2745.12235.

Dynesius, M.; Jonsson, B.G., 1991. Dating uprooted trees; comparison and application of eight methods in a boreal spruce forest. Can. J. For. Res. 21, 655-665

Edman, M., Jönsson, M., Jonsson, B.G., 2007. Small-scale fungal- and wind-mediated disturbances strongly influence the temporal availability of logs in an old-growth Picea abies forest. Ecol. Appl. 17, 482-490.

Engelmark. O., Hofgaard, A., Arnborg, T., 1998. Successional trends 219 years after fire in an old Pinus sylvestris stand in northern Sweden. J. Veg. Sci. 9(4), 583-592.

FAO. 2010. Global forest resources assessment 2010. Terms and definition. Working paper 144/E. http://www.fao.org/docrep/014/am665e/am665e00.pdf.

Fraver, S., Jonsson, B. G., Jönsson, M., Esseen, P., 2008. Demographics and disturbance history of a boreal old-growth Picea abies forest. J. Veg. Sci. 19(6), 789-798.

Fraver, S., D’Amato, A.W., Bradford, J.B., Jonsson, B.G., Jönsson, M., Esseen, P.-A., 2014. Tree growth and competition in an old-growth Picea abies forest of boreal Sweden: influence of tree spatial patterning. J. Veg. Sci. 25, 374-385.

Gauthier, S., Bernier, P., Kuuluvainen, T., Shvidenko, A.Z., Schepaschenko, D.G., 2015. Boreal forest health and global change. Science 349, 819-822.

Giesecke, T. 2004. The Holocene spread of Picea abies (L.) Karst. in Fennoscandia and adjacent areas. J. Biogeogr. 31: 1523-1548.

Granström, A., 1993. Spatial and temporal variation in lightning ignitions in Sweden. J. Veg. Sci. 4, 737- 744.

Grenfell, R., Aakala, T., Kuuluvainen, T., 2011. Microsite occupancy and the spatial structure of understorey regeneration in three late-successional Norway spruce forests in northern Europe. Silva Fenn. 45(5), 1093-1110.

Grove, J.M. 1988. The Little Ice Age. Methuen, London.

Halme, P., Allen, K. A., Aunins, A., Bradshaw, R. H. W., Brumelis, G., Cada, V., Clear, J. L., Eriksson, A-M., Hannon, G., Hyvärinen, E., Ikauniece, S., Iršènaitè, R., Jonsson, B. G., Junninen, K., Kareksela, S., Komonen, A., Kotiaho, J. S., Kouki, J., Kuuluvainen, T., Mazziotta, A., Mönkkönen, M., Nyholm, K., Olden, A., Shorohova, E., Strange, N., Toivanen, T., VanhaMajamaa, I., Wallenius, T., Ylisirniö, A-L., Zin, E., 2013. Challenges of ecological restoration : Lessons from forests in northern Europe. Biol. Cons. 167, 248-256.

Havas, P., Kubin, E., 1983. Structure, growth and organic matter content in the vegetation of an old spruce forest in northern Finland. Ann. Bot. Fenn. 20, 115-149.

Helle, T., Jaakkola, L., 2008. Transitions in herd management of semi-domesticated reindeer in northern Finland. Ann. Zool. Fenn. 45, 81-101.

Hesselman, H., 1912. Om snöbrotten i norra Sverige vintern 1910-1911. Skogsvårdsföreningens Tidskrift 10, 145-172. (In Swedish). 
Hesselman, H., 1917. Studier över de norrländska tallhedarnas foryngringsvilkor II [Studien über die Verjüngungsbedigungen den norrländischen Kiefernheiden]. Meddelanden från Statens Skogförsöksanstalt. (In Swedish with German abstract.).

Hofgaard, A., Kullman, L., Alexandersson, H., 1991. Response of old-growth montane Picea abies (L.) Karst. forest to climatic variability in northern Sweden. New Phytol. 119, 585594.

Hofgaard, A., 1993a. Structure and regeneration patterns of a virgin Picea abies forest in northern Sweden. Journal of Vegetation Science 4, 601-608.

Hofgaard, A., 1993b. 50 years of change in a Swedish boreal old-growth Picea abies forest. J. Veg. Sci. 4, 773-782.

Hofgaard, A., 1993c. Seed rain quantity and quality, 1984-1992, in a high altitude old-growth spruce forest, northern Sweden. New Phytol. 125, 635-640.

Hofgaard, A., 1997. Structural changes in the forest-tundra ecotone: A dynamic process. In: Huntley, B., Cramer, W., Morgan, A.V., Prentice, H.C., Allen, J.R.M. (eds.) Past and future rapid environmental changes: the spatial and evolutionary responses of terrestrial biota. pp 255-263. NATO ASI Series, Vol. I 47. Springer Verlag.

Hofgaard, A., 1999. The role of "natural" landscapes influenced by man in predicting responses to climate change. Ecol. Bull. 47, 160-167.

Hofgaard A., Tømmervik H., Rees G., Hanssen F., 2013. Latitudinal forest advance in northernmost Norway since the early $20^{\text {th }}$ century. J. Biogeogr. 40, 938-949.

Hörnberg, G., Ohlson, M., Zackrisson, O. 1997. Influence of bryophytes and microrelief conditions on Picea abies seed regeneration patterns in boreal old-growth swamp forests. Can. J. For. Res. 27, 1015-1023.

Hörnberg, G., Staland, H., Nordström, E.-M., Korsman, T., Segerström, U. 2011. Fire as an important factor for the genesis of boreal Picea abies swamp forests in Fennoscandia. The Holocene 22(2), 203-214.

Hytteborn, H., Packham, J.R., Verwijst, T., 1987. Tree population dynamics, stand structure and species composition in the montane virgin forest of Vallibäcken, northern Sweden. Vegetatio 72, 3-19.

Hyvärinen, V., Sepponen, P., 1988. Tree species history and local forest fires in the Kivalo area of northern Finland. Folia For. 720, 1-26. (in Finnish).

IPCC. Stocker T. F., et al., (Eds.), Climate Change 2013: The Physical Science Basis. Contribution of Working Group I to the Fifth Assessment Report of the Intergovernmental Panel on Climate Change, Cambridge Univ. Press, Cambridge, 2013). Jepsen, J. U., Hagen, S. B., Ims, R. A., Yoccoz, N. G., 2008. Climate change and outbreaks of the geometrids Operophtera brumata and Epirrita autumnata in subarctic birch forest: evidence of a recent outbreak range expansion. J. Anim.Ecol. 77(2), 257-264.

Jonsson, B.G., 2000. Availability of coarse woody debris in a boreal old-growth Picea abies forest. J. Veg. Sci. 11(1), 51-56.

Jonsson, B.G.; Esseen, P.-A., 1990. Treefall disturbance maintains high bryophyte diversity in a boreal spruce forest. J. Ecol. 78, 924-936.

Josefsson, T., Hörnberg, G., Östlund, L., 2009. Long-term human impact and vegetation changes in a boreal forest reserve: implications for the use of protected areas as ecological references. Ecosystems 12(6), 1017-1036.

Jonsson, B.G., Dynesius, M., 1993. Uprooting in boreal spruce forests: long-term variation in disturbance rate. Can. J. For. Res. 23, 2383-2388. 
Karlsson, H., Shevtsova, A., Hörnberg, G., 2009. Vegetation development at a mountain settlement site in the Swedish Scandes during the late Holocene: palaeoecological evidence of human-induced deforestation. Vegetation History and Archaeobot. 18(4), 297-314.

Kauhanen, H., 2002. Occurrence of fires in the eastern Saariselkä area, North-West Russia. Silva Fenn. 36(1), 383-392.

Keane, R.E., Hessburg, P.F., Landres, P.B., Swanson, F.J., 2009. The use of historical range and variability (HRV) in landscape management. For. Ecol. Manage. 258, 1025-1037.

Kellomäki, S., Peltola, H., Nuutinen, T., Korhonen, K.T., Strandman, H., 2008. Sensitivity of managed boreal forests in Finland to climate change, with implications for adaptive management. Phil. Trans. R. Soc. B 363, 2341-2351.

Koven, C.D., 2013. Boreal carbon loss due to poleward shift in low-carbon ecosystems. Nat. Geosci. 6, 452-456.

Kullman, L., 1991. Cataclysmic Response to Recent Cooling of a Natural Boreal Pine (PinusSylvestris L) Forest in Northern Sweden. New Phytol. 117(2), 351-360.

Kullman, L., 1995. Holocene tree-limit and climate history from the Scandes Mountains, Sweden. Ecology 76, 2490-2502.

Kullman, L., 2001. Immigration of Picea abies into North-Central Sweden. New evidence of regional expansion and tree-limit evolution. Nordic J. Bot. 21, 39-54.

Kullman, L., 2005. Wind-conditioned 20th century decline of birch treeline vegetation in the Swedish Scandes. Arctic 58, 286-294.

Kullman, L., 2008. Early postglacial appearance of tree species in northern Scandinavia: review and perspective. Quarter. Sci. Rev. 27, 2467-2472.

Kullman, L., Öberg, L., 2009. Post-Little Ice Age tree line rise and climate warming in the Swedish Scandes: a landscape ecological perspective. Journal of Ecology 97, 415-429.

Kuuluvainen, T., 1994. Gap disturbance, ground microtopography, and the regeneration dynamics of boreal coniferous forests in Finland: a review. Ann. Zool. Fenn. 31, 35-51.

Kuuluvainen, T., 2009. Forest management and biodiversity conservation based on natural ecosystem dynamics in northern Europe: The complexity challenge. Ambio 38, 309-315.

Kuuluvainen, T., Aakala, T., 2011. Natural forest dynamics in Boreal Fennoscandia: a review and classification. Silva Fenn. 45(5), 823-841.

Kuuluvainen, T., Ylläsjärvi, I., 2011. On the natural regeneration of dry heath forests in Finnish Lapland: a review of V.T. Aaltonen (1919). Scan. J. For. Res. 26 (Suppl 10), 34-44.

Kuuluvainen, T., Wallenius, T.H., Kauhanen, H., Aakala, T., Mikkola, K., Demidova, N., Ogibin, B., 2014. Episodic, patchy disturbances characterize an old-growth Picea abies dominated forest landscape in northeastern Europe. For. Ecol. Manage. 320: 96-103.

Kuusinen, M., 1996. Epiphyte flora and diversity on basal trunks of six old-growth forest tree species in southern and middle boreal Finland. Lichenologist 28,443-463

Lännenpää, A., Aakala, T., Kauhanen, H., Kuuluvainen, T., 2008. Tree mortality agents in pristine Norway spruce forests in northern Fennoscandia. Silva Fenn. 42(2), 151-163.

Larjavaara, M., Pennanen, J., Tuomi, T. J., 2005. Lightning that ignites forest fires in Finland. Agric. For. Meteorol. 132(3), 171-180.

Lassila I., 1920. Tutkimuksia mäntymetsien synnystä ja kehityksestä pohjoisen napapiirin pohjoispuolella. Acta For. Fenn. 14(3), 1-95. (in Finnish).

Lidmar-Bergström, K., Näslund, J.-O., 2005. Major landforms and bedrock. In: Seppälä, M. The Physical Geography of Fennoscandia. Oxford University Press, UK. pp. 3-16 
Lilja, S., Wallenius, T., Kuuluvainen, T., 2006. Structure and development of old Picea abies forests in northern boreal Fennoscandia. Ecosci. 13(2), 181-192.

Linder, P., Elfving, B., Zackrisson, O. 1997. Stand structure and successional trends in virgin boreal forest reserves in Sweden. For. Ecol. Manage. 98, 17-33

Martikainen, P., 2000. Conservation of threatened saproxylic species: signifigance of retained aspen Populus tremula on clearcut areas. Ecol. Bull. 49, 215-218

Mathisen I.E., Mikheeva A., Tutubalina O.V., Aune S., Hofgaard A., 2014. Fifty years of tree line change in Khibiny Mountains, Russia: advantages of combined remote sensing and dendroecological approaches. Appl. Veg. Sci. 17, 6-16.

Messier, C., Puettmann, K., Chazdon, R., Anderssonm K.P., Angers, V.A., Brotons, L., Filotas, E., Tittler, R., Parrott, L., Levin, S.A., 2014. From management to stewardship: viewing forests as complex adaptive systems in an uncertain world. Cons. Lett- 8(5), 368-377.

Moen, A., 1999. National Atlas of Norway. Vegetation. Norwegian Mapping Authority, Hønefoss, Norway.

Niemelä, T., Wallenius, T., Kotiranta, H., 2002. The kelo tree, a vanishing substrate of specified wood-inhabiting fungi. Pol. Bot. J. 47, 91-101.

Neuvonen, S., Niemelä, P., Virtanen, T., 1999. Climatic change and insect outbreaks in boreal forests: the role of winter temperatures. Ecol. Bull. 47, 63-67.

Neuvonen, S., Bylund, H., Tømmervik, H., 2005. Forest defoliation risks in birch forests by insects under different climate and land use scenarios in Northern Europe. Plant Ecology, Herbivory and Human Impact in Northern Mountain Birch Forests (ed. F.-E. Wielgolaski), pp. 125-138. Ecological Studies 180. Springer Verlag, Berlin.

Norokorpi, Y., 1979. Old Norway spruce stands and decay causing microbes in northern Finland. Commun. Inst. For. Fenn. 97, 1-77.

Öberg, L., Kullman, L., 2011. Ancient subalpine clonal spruces (Picea abies): Sources of postglacial vegetation history in the Swedish Scandes. Arctic 64,183-196.

Ohlson, M., Tryterud, E., 1999. Long-term spruce forest continuity: A challenge for a sustainable Scandinavian forestry. For. Ecol. Manage. 124(1), 27-34.

Ohlson, M., Brown, K.J, Birks, H.J.B., Grytnes, J.-A., Hörnberg, G., Niklasson, M., Seppä, H. and Bradshaw, R.H.W. 2011. Invasion of Norway spruce diversifies the fire regime in boreal European forests. J. Ecol., 99, 395-403. doi: 10.1111/j.1365-2745.2010.01780.x

Östlund, L., Bergman, I., Zackrisson, O. 2004. Trees for food - A 3000 year record of subarctic plant use. Antiquity 78, 278-286

Östlund, L., Hörnberg, G., DeLuca, T.H., Liedgren, T., Wickström, P., Zackrisson, O., Josefsson, T., 2015. Intensive land use in the Swedish mountains between AD 800 and 1200 led to deforestation and ecosystem transformation with long-lasting effects. Ambio 44, 508520, DOI 10.1007/s13280-015-0634-z

Overpeck, J.T., Rind, D., Goldberg, R., 1990. Climate-induced changes in forest disturbance and vegetation. Nature, 343, 51-53.

Parducci, L., Jørgensen, T., Tollefsrud, M.M., Elverland, E., Alm, T., Fontana, S.L., Bennett, K. D., Haile, J., Matetovici, I., Suyama, Y., Edwards, M.E., Andersen, K., Rasmussen, M., Boessenkool, S., Coissac, E., Brochmann, C., Taberlet, P., Houmark-Nielsen, M., Krog Larsen, M., Orlando, L., Thomas, M., Gilbert, P., Kjær, K.H., Greve Alsos, I., Willerslev, E., 2012. Glacial survival of Boreal trees in northern Fennoscandia. Science 335, 1083-1086.

Paus, A., Velle, G., Berge, J., 2011. The Lateglacial and early Holocene vegetation and environment in the Dovre mountains, central Norway, as signalled in two Lateglacial nunatak lakes. Quarter. Sci. Rev. 30, 1780-1793. 
Payette, S., Lavoie, C., 1994. The arctic tree line as a record of past and recent climate changes. Environ. Rev. 2, 78-90.

Sprugel, D.G., 1991. Disturbance, equilibrium, and environmental variability: What is 'natural' vegetation in a changing environment? Biol. Cons. 58, 1-18.

Raunio, A., Schulman, A., Kontula, T., (eds.). 2008. The assessment of threatened habitat types in Finland - Part 1: Results and basis for assessment. Finnish Environment Institute, Helsinki. 264 p. (in Finnish with English summary). Available at: http://www.environment.fi/threatenedhabitattypes [Cited 1 Oct 2010].

Stokland, J., Siitonen, J., Jonsson, B.G., 2012. Biodiversity in dead wood. Cambridge University Press.

Scheffer, M., Hirota, M, Holmgren, M, Van Nes, E. H., Chapin, F. S., 2012. Thresholds for boreal biome transitions. Proc. Natl. Acad. Sci. U. S. A. 109, 21384-21389.

Sirén, G. 1955. The development of spruce forest on raw humus sites and its ecology. Acta For. Fenn. 62, 1-363.

Sommerseth, I. 2010. Archaeology and the debate on the transition from reindeer hunting to pastoralism. Rangifer 31, 111-127.

Steijlen, I., Zackrisson, O., 1987. Long-term regeneration dynamics and successional trends in a northern Swedish coniferous forest stand. Canadian Journal of Botany 65(5), 839-848.

Tenow, O., 1972. The outbreaks of Oporinia autumnata Bkh. and Operophthera spp. (Lep., Geometridae) in the Scandinavian mountain chain and northern Finland 1862-1968. Zoologiska Bidrag från Uppsala, (Supplement 2), 107 pp.

Tenow, O., 1996. Hazards to a mountain birch forest - Abisko in perspective. Ecol. Bull. 45, 104-114.

Tenow, O., Bylund, H., 2000. Recovery of a Betula pubescens forest in northern Sweden after severe defoliation by Epirrita autumnata. J. Veg. Sci. 11, 855-862.

Tenow, O., Nilssen, A.C., 1990. Egg cold hardiness and topoclimatic limitations to outbreaks of Epirrita autumnata in northern Fennoscandia. J.f Appl. Ecol., 27, 723-734.

Tenow, O., Nilssen, A.C., Bylund, H., Hogstad, O., 2007. Waves and synchrony in Epirrita autumnata/Operophtera brumata outbreaks. I. Lagged synchrony: regionally, locally and among species. J. Anim. Ecol. 76, 258-268.

Tenow, O., Nilssen, A. C., Bylund, H., Pettersson, R., Battisti, A., Bohn, U., Caroulle, F., Ciornei, C., Csóka, G., Delb, H., De Prins, W., Glavendekić, M., Gninenko, Y. I., Hrašovec, B., Matošević, D., Meshkova, V., Moraal, L., Netoiu, C., Pajares, J., Rubtsov, V., Tomescu, R., Utkina, I., 2013. Geometrid outbreak waves travel across Europe. J. Anim. Ecol. 82, 84-95. doi,10.1111/j.1365-2656.2012.02023.x

Tikkanen, M., 2005. Climate. In: Seppälä, M. The Physical Geography of Fennoscandia. Oxford University Press, UK. pp. 97-112.

Tømmervik, H., Johansen, B., Riset, J.Å., Karlsen, S.R., Solberg, B., Høgda, K.A., 2009. Above ground biomass changes in the mountain birch forests and mountain heaths of Finnmarksvidda, northern Norway, in the period 1957-2006. For. Ecol. Manage. 257, 244257.

Yli-Sirniö, A.-L., Penttilä, R., Berglund, H., Hallikainen, V., Isaeva, L., Kauhanen, H., Koivula, M., Mikkola, K., 2012. Dead wood and polypore diversity in natural post-fire succession forests and managed stands - Lessons for biodiversity management in boreal forests. For. Ecol. Manage. 286, 16-27.

Vajda, A., Venäläinen, A., Hänninen, P., Sutinen, R., 2006. Effect of vegetation on snow cover at the northern timberline: a case study in Finnish Lapland. Silva Fennica 40(2), 195-207. 
Wallenius, T., 2011. Major decline in fires in coniferous forests - reconstructing the phenomenon and seeking the cause. Silva Fenn. 45(1), 139-155.

Wallenius, T., Kauhanen, H., Herva, H., Pennanen, J., 2010. Long fire cycle in northern boreal Pinus forest in Finnish Lapland. Can. J. For. Res. 40, 2027-2035.

Wallenius, T., Pitkänen, A., Kuuluvainen, T., Pennanen, J., Karttunen, H., 2005. Fire history and forest age distribution of an unmanaged Picea abies dominated landscape. Can. J. For. Res. 35, 1540-1552.

Veijola, P., 1997. The use and protection of timberline forests in Finland. Metsäntutkimuslaitoksen tiedonantoja 692, 171 p. (In Finnish with English summary). Willis, K.J. and Birks, H.J.B. 2006. What is natural? The need for long-term perspective in biodiversity conservation. Science 314, 126-126.

Zackrisson, O., 1977. The influence of forest fires on North Swedish boreal forest. Oikos 29, 22-32.

Zackrisson, O., Nilsson, M.-C., Steijlen, I., Hörnberg, G. 1995. Regeneration pulses and climate-vegetation interactions in nonpyrogenic boreal Scots pine stands. J. Ecol. 83: 469-483. 
818 Fig. 1. The geographic region (dashed area) indication the mountain forests that are in focus in this paper. Grey shows the distribution of forest.

Fig. 2 Pine forest in different site types and developmental stages. (a) Old pine forest with standing and fallen Kelo trees (Maltio Strict Nature Reserve, Finnish Lapland). (b) Paludified pine forest on mountain slope (central Norway). (c) Burned pine forest with deciduous regeneration (Murmansk region, Russia). (d) Abundant pine regeneration after forest fire (Murmansk region, Russia). Photos: Timo Kuuluvainen.

Fig. 3 Forest dynamics stages in mostly spruce dominated moist forests. (a) Old spruce dominated forest with thick raw humus layer (Värriö Strict Nature Reserve, eastern Finnish Lapland. (b) Burned spruce forest with abundant deciduous regeneration (Murmansk region, Russia). (c) Canopy gap in old spruce forest with deciduous regeneration (Murmansk region, Russia). (d) young deciduous forest regenerated after fire in a spruce forest (Pallas-Ylläs National Park, Finnish Lapland. Photos: Timo Kuuluvainen.

833

Fig. 4. Mountain birch forest is characterizing large parts of the North Fennoscandian mountain region. (a) Birch trees and forest in autumn color (Abisko, northwestern Sweden). (b) Grass-dominated (Descampsia flexuosa) forest floor one year after tree canopy

837 defoliation by autumnal moth (Epirrita autumnata) and subsequent nutrient release (Abisko, 838 northwestern Sweden). (c) Slush avalanche track in birch forest, (Tärna Mountains, Sweden).

839 (d) Former mountain birch forest turned into tundra after autumnal moth outbreaks in the 8401960 s (Kevo area, northern Finland). Photos: Annika Hofgaard (a)-(c) and Timo Kuuluvainen 841 (d). 
$\overrightarrow{0}$

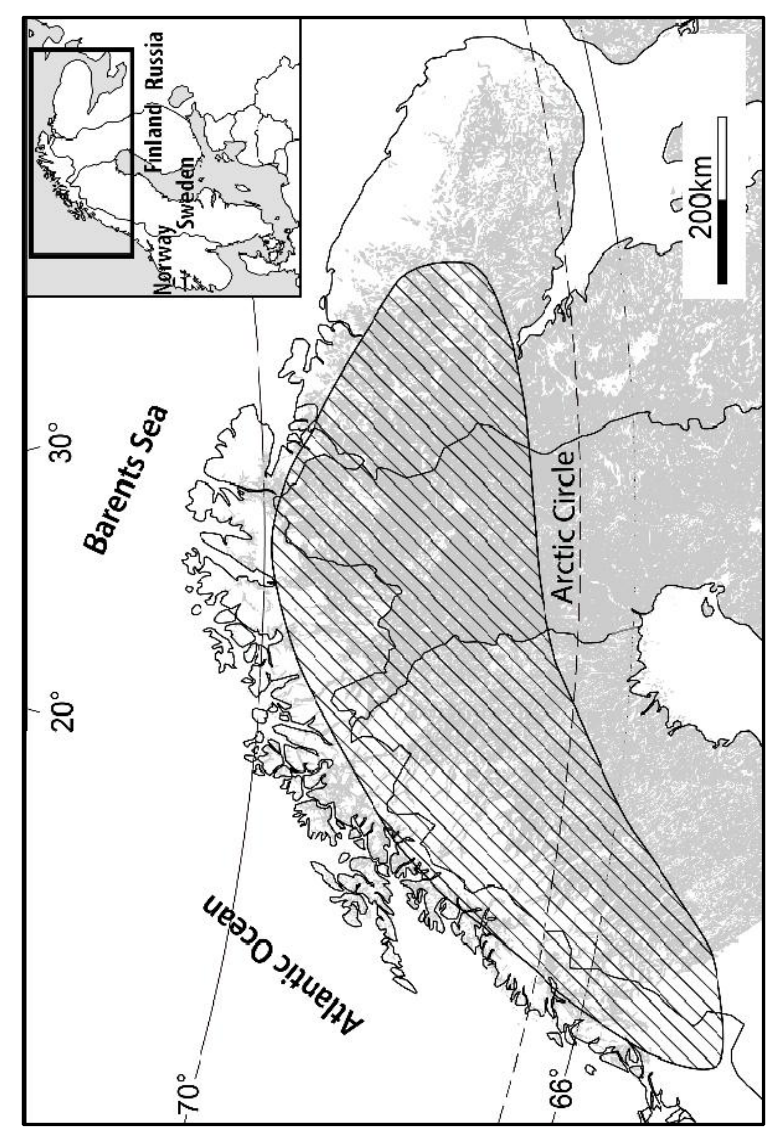


$\frac{1}{i \frac{0}{1}}$
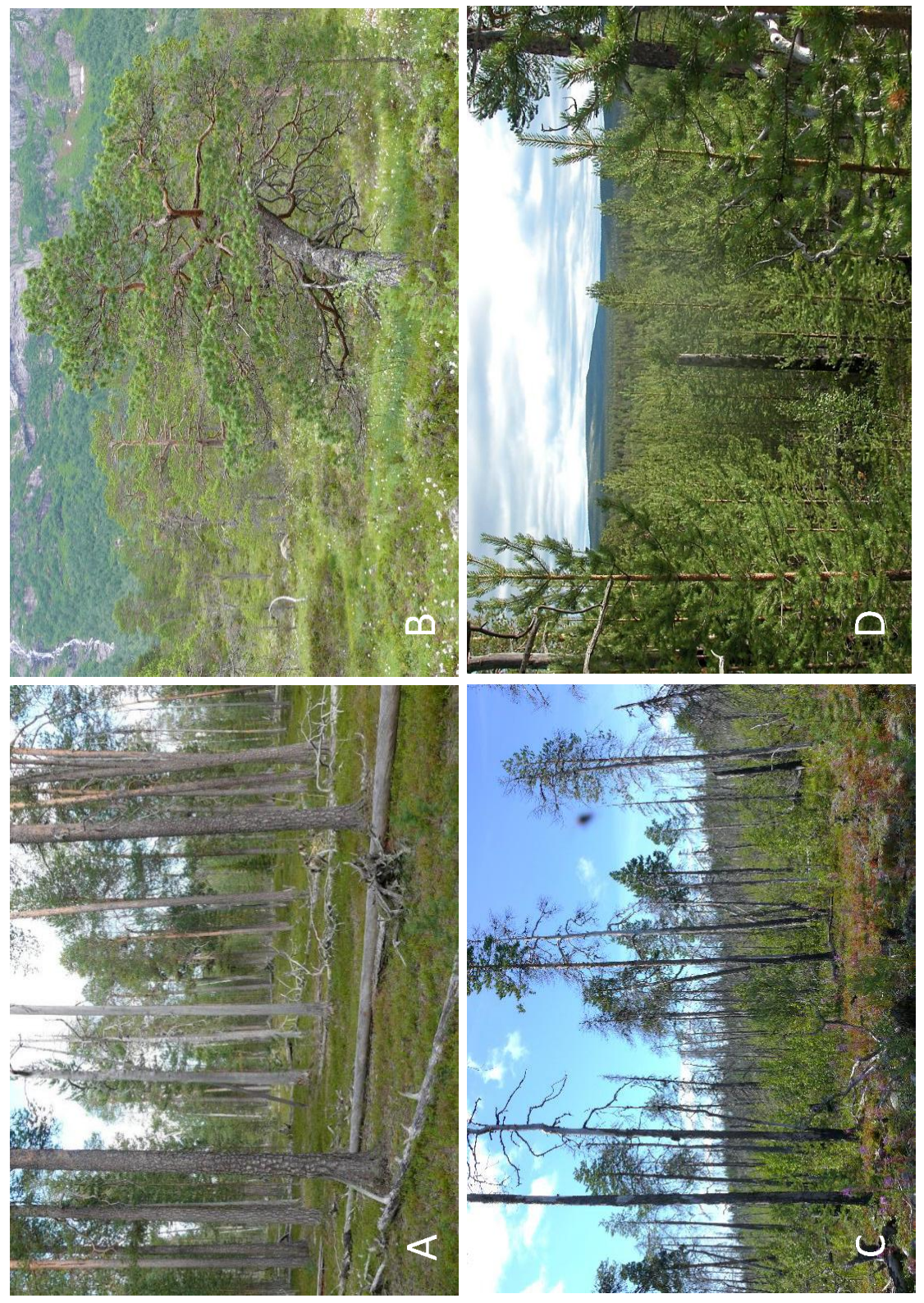
$m$

모
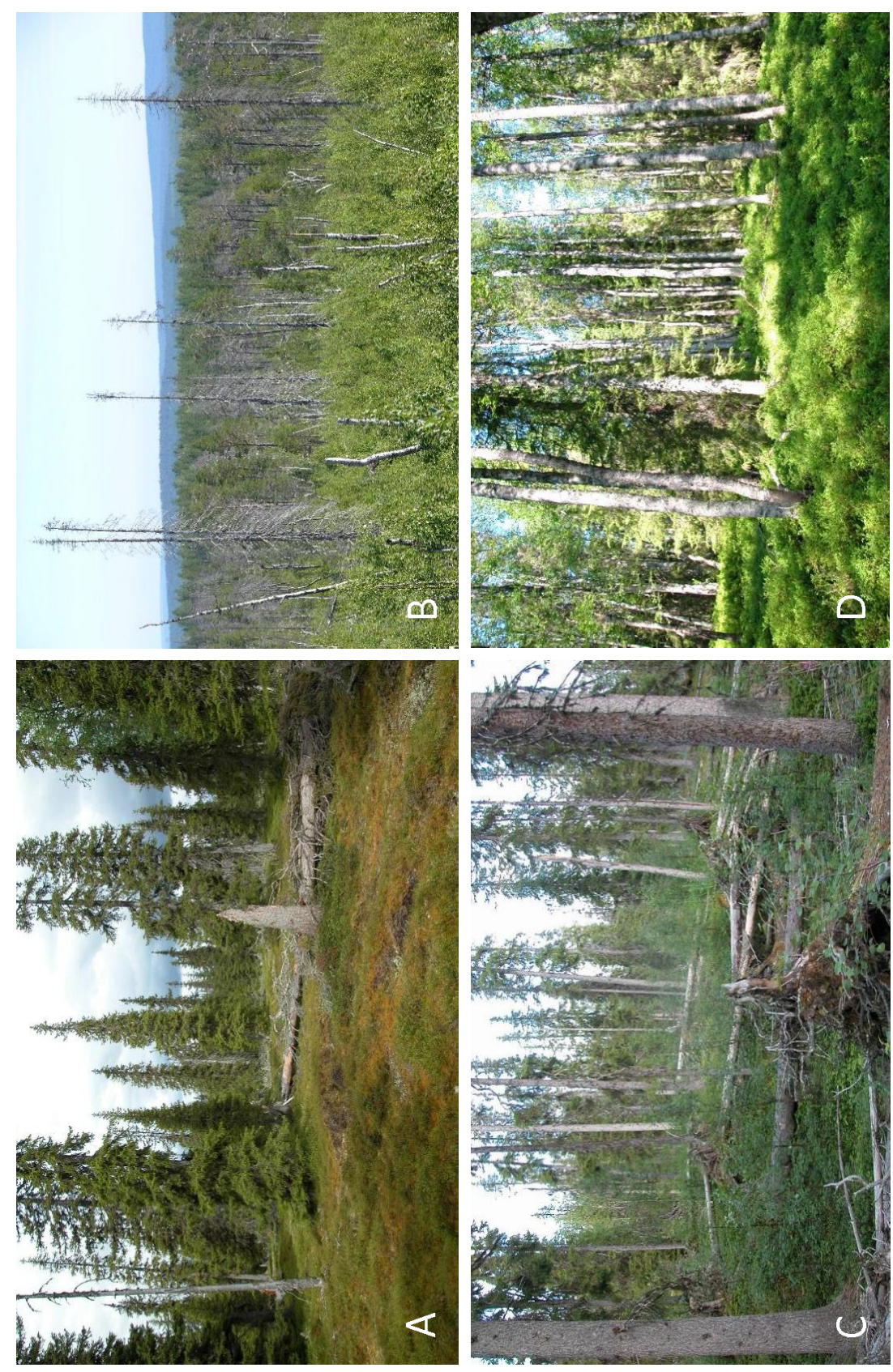
$\nabla$
후
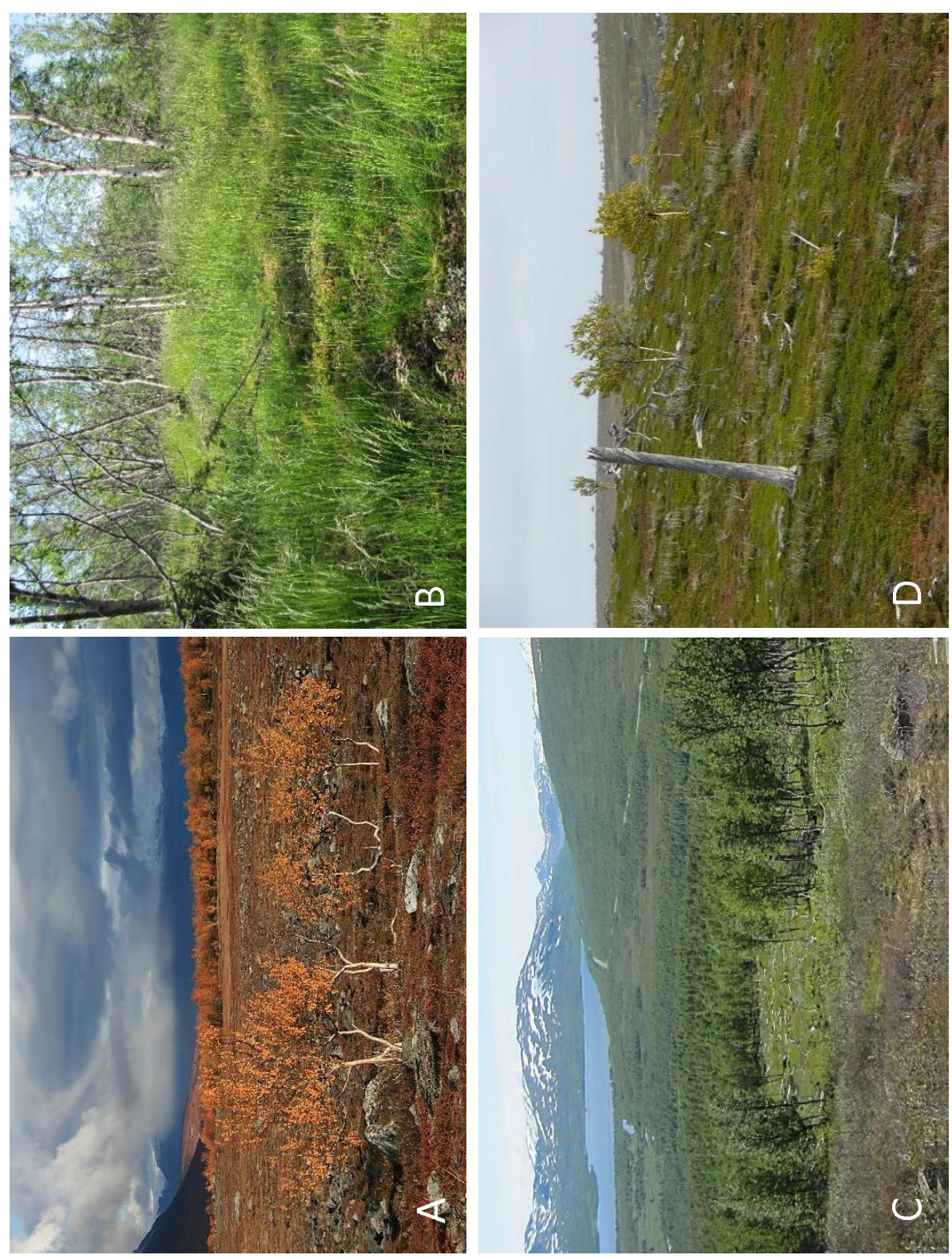


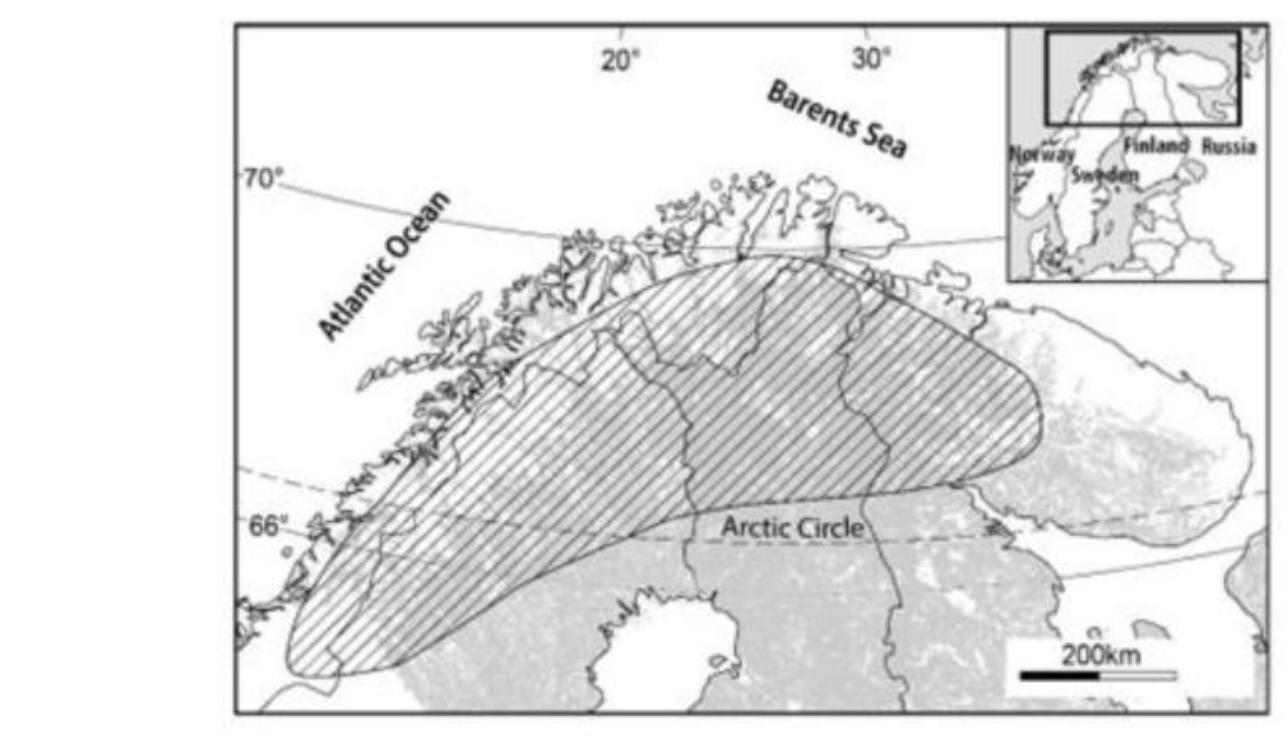

